\title{
LOYALTY - THE NUCLEUS OF BRAND CAPITAL. CASE STUDY: ROM CHOCOLATE BAR
}

\author{
Brîndusa-Mariana Amalancei \\ "Vasile Alecsandri” University of Bacău \\ brandusa_amalancei@yahoo.com
}

\begin{abstract}
It is considered that loyalty to the brand of some primary customers is the core of the brand capital. A brand, however, may have substantial value, which is given to it by its symbol and slogans, if it is continued with the purchase of a brand after the buyers have made a comparison with the competing products that have superior characteristics. Structured on several levels, which are each a different marketing challenge, the loyalty to the brand consists of many factors, among which the most important is the user experience. The paper aims to highlight, starting from a series of articles in online media, the manner in which a traditional Romanian brand, ROM chocolate bar, continuously repositions itself, attempting to maintain and even increase the loyalty of its consumers, as well as to answer the consumer's authenticity, accessibility, credibility and modernity needs. Even though in specialized literature there are opinions according to which traditional brands are commonly oldfashioned or dull, ROM chocolate bar shows the opposite view, being considered a successful brand which is appreciated both at national and international levels.
\end{abstract}

\section{Keywords}

image; personality; identity; brand awareness; brand commitment

\section{JEL Classification}

M37

\section{Introduction}

Having become a real social and cultural phenomenon, in our times brands have an almost immeasurable power in business, as well as in politics, arts, sports or charity. Brands can be of all forms and sizes - specific or generic, tangible or intangible, global, regional or national, cheap or expensive -, but their force generally results not only from what they are, but also from what they represent (Olins, 2006).

However, it is quite difficult to find a definition of brands which could comprise all the dimensions of this concept. That is why certain authors choose to define a brand by means of what it is not, thus leaving room for open interpretation: "A brand is NOT a logo. A brand is NOT an identity manual. A brand is NOT a product or a service. A brand is NOT a label or a package. A brand is NOT a business plan. A brand is NOT some kind of fashion or one of its trends. A brand is NOT a manufacturing process. A brand is NOT a name or a slogan. But what is a brand? Above all, a brand is a PROMISE! A promise made firmly, clearly and for everlasting time. It is a promise that all the expectations of the consumers related to the product, service, or person, will be fulfilled. That is why we can say that a brand is what the others think about it" (Caramida, 2009). Therefore, being more than a word, a logo or an identification symbol, a brand is a heterogeneous blending of perceptions, emotions, or attitudes regarding a product, making reference to its qualities, or to its tangible and intangible aspects. 
A series of terms connected to the brand concept also exists, and their definition is important for accurate conceptual distinctions:

- $\quad$ the name of a brand can consist of a word, letters or numbers used separately or in different combinations;

- the image of a brand is an essential factor, for the reason that its public representation is directly proportionate to the public trust in that brand;

- brand personality involves the association of a brand, especially by means of advertising, with certain personality traits, with the purpose of differentiation;

- the identity of a brand brings together a series of elements, starting from the name of the brand, with the purpose of differentiation;

- brand awareness involves brand recognition (that is, consumers' confirmation of previous contact with that brand) and brand recall (the identification of the brand by the consumers when they are offered a product belonging to a certain category or a clue related to the brand product), but it does not necessarily imply the acquisition of the brand or attraction to it;

- brand commitment refers to the consumer's connection or the degree of commitment to a brand, which will result in repeated purchase and use of the brand (Balaban, 2009).

\section{Dimensions of brand capital}

In effect, loyalty to a certain brand shown by devoted consumers represents the nucleus of brand capital. When consumers continue to purchase a brand after comparing it with competing products which possess superior qualities, we can speak about a substantial value of the brand, which probably derives from its symbol and slogans, as well. Brand loyalty can be structured on a few levels, each of them representing a different marketing challenge (figure 1):

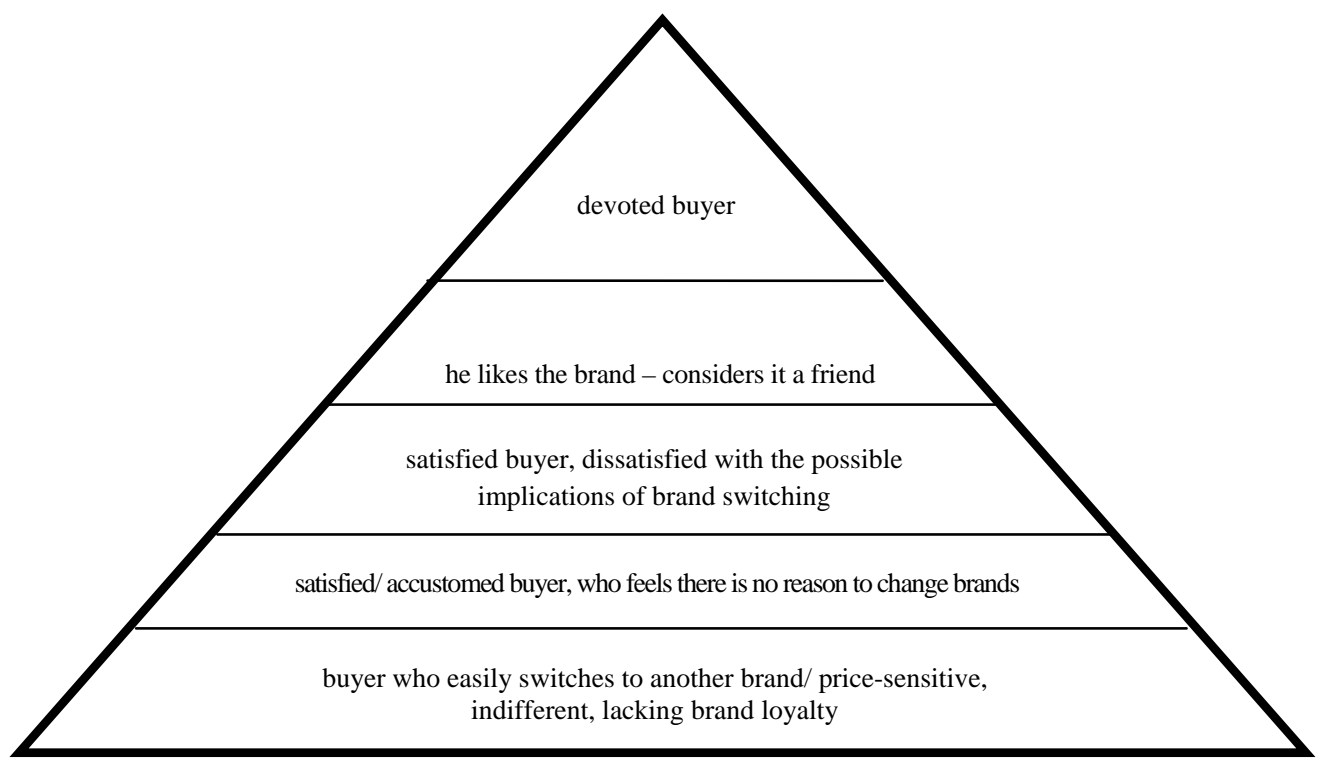

Figure 1 - Loyalty Pyramid

Source: Aaker, D. (2005), Managing brand equity. Capitalizing on the value of a brand name, Brandbuilders Grup Publishing, Bucharest, pp. 65 
The broad-based bottom of the loyalty pyramid corresponds to the changeable/unstable buyer, who is totally indifferent to the brand and for whom any brand is adequate, whereas the name the brand has a very insignificant role for his buying decision. This type of buyer can easily be transferred in the category of buyers who will choose another brand, guiding their decisions on the basis of convenient or low prices. The second level consists of buyers who could be considered accustomed and who are satisfied with a product or, at least, are not dissatisfied with it. In fact, possible dissatisfaction is not sufficient to stimulate the brand switching desire, especially if this change involves effort. At the third level we can identify those consumers whose loyalty is determined by costs (in terms of time, money or performance) brought about by brand switching. This type of consumer can be attracted by the competition by means of reductions or benefits which are significant enough to compensate for switching costs. The fourth level is represented by the socalled 'brand friends' who prefer the brand because they associate it with a symbol, previous use experiences of high quality rates. However, the preference for one brand or another cannot commonly be determined precisely. Finally, the fifth level includes devoted buyers who take pride in the discovery of the brand and in their condition as first users of the brand. For these buyers, the significance of the brand lies in its functions or in the fact that the brand represents the expression of their identities, while their trust in the brand will make them recommend the brand to others, too. Even though these five levels can only exist in a conceptual condition and do not always appear in a pure form, they can nevertheless reflect the existing variety of forms loyalty can take and the manner in which this aspect can affect brand capital. Brand loyalty lies at the basis of brand capital and is formed of numerous factors, among which the brand experience is the most important one. Still, loyalty is partly determined by major dimensions of brand capital such as, for instance, recognition, associations and perceived quality, but it cannot always be explained by virtue of these factors (Aaker, 2005).

Most brands show the desire to generate more energy and this is explained by the fact that successful brands seem to possess energy. In case of traditional brands, although they are considered trustworthy, honest, accessible and innovative, still, most often, they are regarded to be old-fashioned, obsolete, or boring, which can have an impact on their relevance for certain market segments. It is thus believed that "an element which confers energy to the brand is a product, a promotion, a sponsorship, a symbol, a programme or any other brand element which, by means of association, significantly improves and energizes the target-brand, thus actively managing both the energy source and its associations with the target-brand over a long time span" (Aaker, 2006).

\section{Case Study: ROM Chocolate Bar}

A traditional brand which can be considered successful on the Romanian market is ROM chocolate bar, produced by Kandia, a company whose history dates as far back as 1895 when it had only six employees, in a candy factory in Timişoara. In 1920, the number of employees reaches 300, and in 1948 nationalization occurs. In 1964, the first Rom chocolate bar appears on the market, whose recipe was modified, as a consequence of the living conditions of those times, first by giving up milk, and then by introducing substitutes in the rum filling (figure 2). 


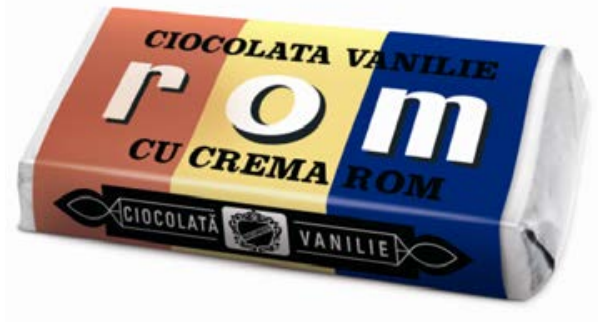

Figure 2 ROM Rum and Vanilla Cream Chocolate Bar

Source: http://www.citadinul.ro/2013/07/6-reclame-la-ciocolata-rom-tricolor-comentate/, accessed on 1.10.2013

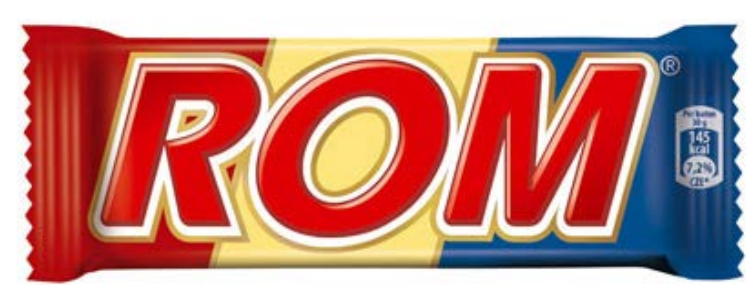

Figure 3 ROM Authentic Rum Bar

Source: http://www.kandia-dulce.ro/brand/rom/, accessed on 1.10.2013

Rom chocolate bar was relaunched by Kandia in 2005 by means of the campaign Rom. Strong sensations. Romanian sensations. Starting from 1964 (Dumitru, 2013) - figure 3.

On the company's site, the name of this campaign is clearly explained: "To talk about Rom means to talk about Romanians and Romania. A witness of socio-political events and changes, Rom is the chocolate bar many of us were raised with. Rom has remained relevant even for the younger ones because it is a part of our history, it is the authentic Romanian taste, proud of its identity, which causes strong sensations even now, and which are best understood by the Romanians. In its more than 48 years on the market, Rom has maintained its identity, as well as its strong taste of rum, and the same package showing the Romanian national colours”.

Therefore, the product has retained its form and its package has long maintained the marks of the Romanian colours, thus proving that it does not need continuous reinvention. The only changes brought to the chocolate bar are related to its package quality, now with a more lustrous package surface, and its dimensions (ROM "the Great" or "the Double"), and in this way it has answered the increasing demand of the consumers who are fond of the strong sensations awoken by the taste of ROM chocolate bar.

However, in 2010, on the package of the chocolate bar, instead of the Romanian flag, the American flag appeared, together with the slogan "The taste of coolness" (figure 4). 


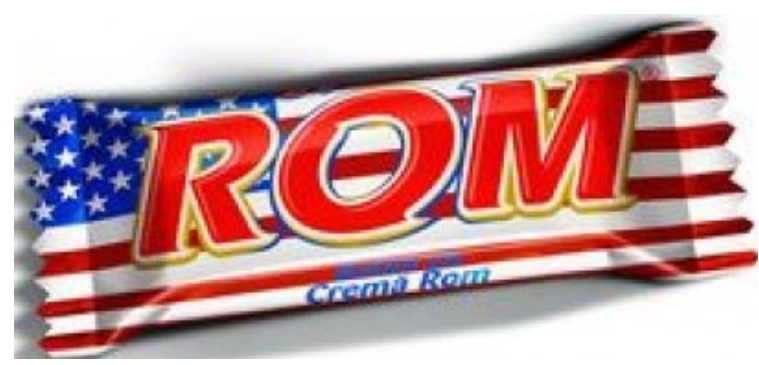

Figure 4 New ROM

Source: http://www.wall-street.ro/articol/Marketing-PR/93279/Ciocolata-Rom-isi-pune-pe-ambalajsteagul-american-ca-sa-porneasca-o-dezbatere-despre-valorile-romanesti.html, accessed on 2.10.2013

The campaign's main objective, as shown by the press release which announced the change, included the boosting up of sales, especially among the younger generation, as well as the enhancement of brand indicators, the consolidation of its market position and the reinvigoration of its image with the aim of attracting a younger target (Mistreanu, 2010).

The replacement of the Romanian flag with the American one on the bar's package instantaneously caused the disapproval of the Romanians in social media. Thus, some Facebook users organised a campaign which called for the reintroduction of the original package. Blogs also wrote about this change. In fact, ROM intended to initiate a debate related to the Romanian values which have been forgotten lately. The Facebook group "We want authentic ROM chocolate back" managed to attract thousands of fans, be they previous chocolate consumers or not. As a result, after only ten days, Rom chocolate bar reintroduced the package which showed the Romanian flag, together with a quite aggressive campaign which claimed that "Rom is back for you. Congratulations for the vigour with which you called back 100\% Authentic Romanian ROM” (Pascu, 2010).

Mention should be made that, even though over the last twenty years important changes occurred in the factory which produces the chocolate bar, the product has been manufactured without interruption, recording value increases of more than $10 \%$ annually (Grajdeanu, 2009) and it has thus managed to remain in the top of bestselling chocolate bars. It is considered that ROM is a brand which has proved to be successful in Romania according to Philip Kotler's 4Ps (price, product, place, promotion), the strategic secret of this product lying in the wish to attract young people and to bring up to date a brand which was born in communist times (Roșca, 2012).

The promotional campaigns for ROM chocolate are unconventional and always constitute a challenge which aims to stimulate the viewer and, most of all, to create a national image and brand. Some of these (2005) were built on the idea of a rebellious attitude against the rigours imposed by the communist doctrine (commercials such as "The work visit"; http://www.youtube.com/watch?v=05BsN9BKoFI, accessed on 3.10.2013 or "The Roaker" ${ }^{1}$; http://www.youtube.com/watch?v=TOrZoD3uv6M, accessed on 3.10.2013), and replies such as "The party wants you to get a haircut!" have become clichés and are still the subject of substitutions, parody or pastiche in common speech, although the commercial has no not been shown on TV for a long time. Others, dating from 2008-2009, were created by associating Rom chocolate with

\footnotetext{
1 "roaker" is a distorted linguistic form of the English word "rocker".
} 
a musical genre called "manele" - a controversial musical genre, which nevertheless managed to impose itself on the Romanian musical market and even attracted fans among certain categories of the population, including quite a large number of young people - or with Dragobete's Day (http://www.youtube.com/watch?v=OLWf7ccI0Xk, accessed on 3.10.2013), thus taking advantage of the moment when this celebration was reinstituted as a tradition in Romania. The slogan “On Dragobete's Day, love in the Romanian way” had a strong public appeal, being used as the name of numerous events organised for the celebration of this day. However, it seems that the most daring campaign was that from 2010, "The new ROM. Let's build America" (http://www.youtube.com/watch?v=ktGGv0tPamQ, accessed on 3.10.2013), when the Romanian flag on the chocolate package was replaced by the American flag. The idea at the basis of this campaign, whose objectives were mentioned above, generated a public debate on the topic of nationalism, Romanian values and Romanian identity, and it also engendered numerous petitions and demonstrations calling for the reintroduction of the authentic Rom. In the same year, this idea also constituted the opportunity to create a new commercial (http://www.youtube.com/watch?v=W8bh43ijhyc, accessed on 3.10.2013), which includes an anthem in praise of Rom chocolate, thus confirming the attachment of the Romanian people to their colours, tradition, and values. The latest promotional campaign for Rom chocolate (2013) is by no means less inspired. Starting from the idea that Romania occupies the $5^{\text {th }}$ position in the international top of geographical confusions, the commercial explains the difference between Bucharest and Budapest, the two cities being often confused with one another as a result of the similarity between the names of the two capitals in English. The campaign "Bucharest NOT Budapest" managed to attract the attention of many TV stations and was even awarded at the Golden Drum festival in Slovenia (Bunea, 2013). The same happened in 2012, at Cannes Advertising Festival, with the campaign entitled "The Romanians are Smart" (Silver Lion award for Direct Lions category - Best Low Budget Campaign) - a campaign launched in 2011, due to which Romania became the first country in the world which changed its image on the internet (Campania "Romanii sunt Destepti" castiga Silver Lion la Festivalul de la Cannes, 2012) - or in 2011, at international festivals in Prague and New York, where the campaign "ROM. Changing the Romanian Flag" obtained a Golden Award in the SABRE Awards competition, Consumer Marketing - Existing Product category, and a silver medal and two bronze medals in sections "Marketing Effectiveness: Consumer Products and Services”, "Integrated Media: Product \& Service”, "Public Relation/Brand Communications: Product and Services Consumer" (Campania "Noul Rom", premiata la SABRE si la New York Festivals, 2011).

As a result of the fact that it has maintained a constant relationship with its own clients, ROM won a place in the book WorldWideBrands, from which we have extracted a relevant excerpt: "Rom has managed to become a brand which is cool enough for the young people, thus succeeding to make the connection between past and present times. Rom urges you to say what you think, to be what you are and thus to have the courage to be different. Rom pulled through in the hardest of times, spoke openly about what Romania means and awoke in the Romanians the attachment for their country when everyone wanted to leave abroad. Rom makes the best of a bad bargain because it is the sense of humour which characterizes us, the Romanians.

\footnotetext{
${ }^{2}$ the equivalent of St Valentine’s Day.
} 
Rom speaks with humour and with a touch of irony about the Romanians and Romania, revealing strong, authentic sensations” (Munteanu, 2011).

\section{Conclusions}

We believe that ROM brand is characterised by tradition, authenticity, distinction, trust and recognition. According to a study conducted by Unlock Market Research exclusively for Biz magazine and published on July 222013 at www.revistabiz.ro, it is the second consecutive year when Authentic Rom occupies a place in top 10 brands considered to be fascinating by the Romanians, thus going up with two positions as compared to 2012. It is important to mention that the test group for this top was formed of 600 respondents aged 18 - 55, who were interviewed over the phone using CATI questionnaires. The evaluated brands belonged to four product categories, the maximum admissible level being of eight categories, and a series of pragmatic and emotional factors were taken into consideration, attributes which are specific to the concept of fascination. Thus, each brand was associated with a coefficient of fascination, and the results obtained formed the top 50 most fascinating brands (Barliga, Sandulescu, 2013).

ROM brand has managed, throughout time, to make itself admired/appreciated and respected, to be friendly, to win the trust of the Romanian people, building the bridge between the past and the present, laying its foundations on humour, tradition and innovation and thus securing the consumer's loyalty.

\section{References}

Aaker, D. (2005), Managing Brand Equity. Capitalizing on the Value of a Brand Name, Brandbuilders Grup Publishing, Bucharest.

Aaker, D. (2006), Brand Portfolio Strategy: Creating Relevance, Differentiation, Energy, Leverage and Clarity, Brandbuilders Grup Publishing, Bucharest.

Balaban, D.C. (2009), Advertising. From Strategic Planning to Implementation Media, Polirom Publishing, Iaşi.

Barliga, G., Sandulescu, L. (2013), Top 50 Branduri fascinante in Romania, available on http://www.revistabiz.ro/top-50-branduri-fascinante-in-romania-1317.html.

Bunea, I. (2013), Campania Gândul „Why don`t you come over”, marele premiu la festivalul Golden Drum, available on http://www.paginademedia.ro/2013/10/campania-gandul-why-dont-you-comeover-marele-premiu-la-festivalul-golden-drum/.

Campania "Noul Rom", premiata la SABRE si la New York Festivals (2011), http://www.wall-street.ro/articol/Marketing-PR/104058/Campania-Noul-Rompremiata-la-SABRE-si-la-New-York-Festivals.html.

Campania "Romanii sunt Destepti” castiga Silver Lion la Festivalul de la Cannes (2012), available on http://www.kandia-dulce.ro/campania-romanii-suntdestepti-castiga-silver-lion-la-festivalul-de-la-cannes/.

Caramida, C. (2009), Brand\&Branding. Visual Identity, I, Brandmark Publishing, Bucharest.

Dumitru, E. (2013), Reinventarea brandurilor româneşti din „Epoca de Aur“, available on http://www.historia.ro/exclusiv_web/actualitate/articol /reinventarea-brandurilor-romanesti-epoca-aur,

Grajdeanu, A. (2009), Rom Autentic, vector de vânzări pentru Cadbury, available on http://www.money.ro/rom-autentic-vector-de-vanzari-pentrucadbury_455896.html. 
Mistreanu, S. (2010), Ciocolata Rom isi pune pe ambalaj steagul american ca sa porneasca o dezbatere despre valorile romanesti, available on http://www.wall-street.ro/articol/Marketing-PR/93279/Ciocolata-Rom-isipune-pe-ambalaj-steagul-american-ca-sa-porneasca-o-dezbatere-desprevalorile-romanesti.html.

Munteanu, A. (2011), O carte despre brandurile îndrăgostite de consumatorii lor, available on http://www.romanialibera.ro/bani-afaceri/angajari/o-carte-desprebrandurile-indragostite-de-consumatorii-lor-243697-pagina1.html.

New ROM [Image], (2013), Available on http://www.wallstreet.ro/articol/Marketing-PR/93279/Ciocolata-Rom-isi-pune-pe-ambalajsteagul-american-ca-sa-porneasca-o-dezbatere-despre-valorile-romanesti.html.

Olins, W. (2006), On Brand, Comunicare.ro Publishing, Bucharest.

Pascu, R. (2010), Ciocolata ROM - sau ce inseamna sa stii Marketing, available on http://razvanpascu.ro/2010/10/10/ciocolata-rom-sau-ce-inseamna-sa-stiimarketing/.

ROM Authentic Rum Bar [Image], (2013), available on http://www.kandiadulce.ro/brand/rom.

ROM Rum and Vanilla Cream Chocolate Bar [Image], (2013), available on http://www.citadinul.ro/2013/07/6-reclame-la-ciocolata-rom-tricolorcomentate.

Roșca, C. (2012), Brandurile care au trecut testul timpului: Câte generaţii au trecut peste ciocolata Rom, demachiantul Doina sau vinul Murfatlar?, available on http://www.zf.ro/companii/brandurile-care-au-trecut-testul-timpului-categeneratii-au-trecut-peste-ciocolata-rom-demachiantul-doina-sau-vinulmurfatlar-10357858. 